\title{
Social Media and Political Marketing: A Case Study of Malaysia During the 2018 General Election
}

\author{
Prof. Samsudin A. Rahim \\ Emeritus Professor School of Communication, Taylor's University Malaysia. \\ (Samsudin.AbdRahim@taylors.edu.my)
}

Keywords: General election, Malaysia democracy, social media, political marketing and campaign.

\begin{abstract}
As the time goes by, political campaign and marketing have entered social media quickly. In this era people were more interested in accessing social media than conventional media social media is obviously very different from the mass media. Although it has been more than 10 years since Obama used social media and won the American presidential campaign, not much theorising has been done about the relationship between social media and political success. Nevertheless, social media keeps getting the credit for successful political campaigns. Social media contributes to successful campaigns in many ways, but it is not the only factor. In the UK's 2017 general election, social media was found to help the voters understand parties' policy positions, and engagement with social media made them more likely to vote. In Malaysia, social media as political marketing and campaign used in 2018 General Election which combine Barisan Nasional (BN) and Pakatan Harapan (PH). The purpose of this research is to analyse how social media are used by both politicians to dominate the election.
\end{abstract}

\section{INTRODUCTION}

Social media has become an indispensable medium for political marketing and campaigns. Social media differs from mainstream media in terms of form and function, and they bring about different effects on the voters' interest, knowledge, engagement, and turnout in elections. In the UK's 2017 general election, social media was found to help the voters understand parties' policy positions, and engagement with social media made them more likely to vote (Kaminska et.al. 2017). In the social media campaign environment, is has been suggested that the campaign is more candidatedriven as opposed to issue-driven. Politicians have been directly exposed to people with rather specific demographic characteristics and political interests (Diaz, Gamon, Hofman, Kicıman, \& Rothschild, 2016). Candidates might therefore tailor their communication to the sociotechnical environments of platforms like Facebook, WhatsApp, and Twitter. This paper will discuss how a properly formulated social media strategy can help win an election. In this particular case, Pakatan Harapan (PH), Malaysia's main opposition coalition, managed to topple Barisan Nasional (BN), which had governed Malaysia for the last 60 years. Social media by itself cannot win an election, but with properly packaged messages that can reach a specific segment of voters, social media can effectively help a candidate or party to victory.

\section{METHODS}

This Research used descriptive qualitative methods. Main data and information about political campaign through social media during the 2018 General Election collected by observation, literature research, and online data such as media text analysis. This research also using comparative studies between the election when Obama's era and Malaysia's $14^{\text {th }}$ General Election. 


\section{RESULT AND DISCUSSION}

\subsection{Malaysia's $14^{\text {th }}$ General Election}

Malaysia's 14th general election (GE was dubbed the 'mother of all elections' because Barisan Nasional (BN), the ruling party of the 13-party coalition, was facing a formidable challenge from a newly formed opposition coalition of four parties, Pakatan Harapan (PH). To make this election look like a 'battle royal', both parties were led by strong personalities, namely Datuk Najib Razak, the incumbent prime minister and chairman of BN, and Tun Dr. Mahathir Mohammed, a former prime minister of 22 years and now chairman of $\mathrm{PH}$. The personalities and images of these two political heavyweights played an important part in attracting voters to support their coalitions in the election held on 9 May 2018. History was made when the formidable $\mathrm{BN}$, which has ruled Malaysia for the last 60 years, was unexpectedly toppled in spite of forecasts by many political pundits that BN would win the election but with a reduced majority.

The result of the 14th GE was a real nightmare for BN. Not only did they lose, but they lost badly. The PH coalition, with the support of WARISAN, a friendly regional party, won 125 of 222 seats in the lower house of parliament. BN won only 76 seats, a big reduction from the 133 seats that it held coming into the election. Following the surprise defeat, most coalition partners decided to break away from $\mathrm{BN}$, leaving $\mathrm{BN}$ with many fewer seats54 - at the start of parliamentary session on 14 July 2018. The breakaway parties of $\mathrm{BN}$ in Sarawak formed their own coalition, Gagasan Persatuan Sarawak (GPS), which now controls 19 seats and has declared itself friendly to the ruling federal government led by $\mathrm{PH}$. The other 18 seats were won by the Malaysian Islamic Party (PAS).
Table 1: Parliamentary Seats by Political Parties

\begin{tabular}{|c|c|}
\hline PH & $\mathbf{1 0 7}$ \\
\hline BN & $\mathbf{5 7}$ \\
\hline GPS & $\mathbf{1 9}$ \\
\hline PAS & $\mathbf{1 8}$ \\
\hline DAP & $\mathbf{9}$ \\
\hline WARISAN & $\mathbf{8}$ \\
\hline STAR & $\mathbf{1}$ \\
\hline IND & $\mathbf{3}$ \\
\hline TOTAL & $\mathbf{2 2 2}$ \\
\hline
\end{tabular}

The unexpected major swing towards the opposition, dubbed the Malaysian Tsunami, stripped BN of its power over not only the federal government but also many states' legislative councils. Despite controlling 10 out of the 13 states' assemblies coming into the election, BN only managed to secure majority in two state assemblies. The defeat was devastating for $\mathrm{BN}$, especially coming from a newly formed coalition of four parties that was led by Tun Dr. Mahathir Mohammed, who was once the Chairman of BN and had led them into four successful general elections.

Ever since the 12th general election in 2008, BN has faced political threats from the opposition coalition of Pakatan Rakayat (PR), which won control of three state assemblies but shied away from controlling the federal government, winning only 82 seats in 2008 and 89 seats in the 2013 general election. BN's share of the popular vote has been declining: In 2013, it only won $47 \%$ of the popular votes and lost its twothirds majority in the lower house of parliament (ST, Oct17, 2015).

The 14th general election was called in the midst of a drawn-out scandal of corruption and financial management involving a state-owned investment entity, the 1 Malaysia Development Berhad (1MDB), which pinned down Najib Razak as a central figure due to his position as prime minister, finance minister, and special advisor to 1MDB. In addition, there was the bread-and-butter issue of the rising cost of living due to the implementation of the 
Goods and Services Tax (GST). The rise of regional nationalism in the two Borneo states of Sabah and Sarawak led to a surging unfavourable feeling toward the federal government.

\subsection{How Social Media Helps Win an Election}

Barack Obama's successful social media campaign, which enabled him to be elected as the first black president of the United States in 2008, was a game-changer leading politicians to incorporate social media as one of their campaign communication tools (Miller, 2008). The successful Arab Spring was another example used to support the successful use of social media in a mobilisation movement that sparked uprisings of citizens against their governments (Brown, Guskin and Mitchell, 2012). In both cases, did social media play a crucial role in winning the election and mobilising the masses?

The medium is not the message. For any communication channel to be successful, it must integrate relevant messages so as to fulfil its target audience's need for information. In the case of social media, the mostly horizontal communication offers a greater advantage than the vertical communication offered by the mass media. The horizontal communication on social media connects individuals, groups, and communities into a bigger social network as the weak ties among smaller networks become stronger. Small-scale interactions can now become large-scale patterns.

In the just-concluded Malaysian general election, the campaign could be described as a battle on social media. Currently, there are 24 million social media users in Malaysia, which represents $75 \%$ of the total population. Out of that number, 22 million $(69 \%)$ are active mobile social media users. The BN campaign utilised all mass media under its control to carry its message to its strongholds in the rural areas where the population has less access to social media. However, $\mathrm{BN}$ is also strong on the social media front. It was reported that 3,500 cyber troopers attended a $\mathrm{BN}$ rally in Kuala Lumpur organised by BN's IT bureau.

However, the PH campaign, which was deprived of utilising the governmentcontrolled mass media, had from the preelection period focused on social media to announce events, transmit messages, and as well go 'live' at its major campaign events to its mostly urban voters. For its messaging targeting rural voters, $\mathrm{PH}$ opted for a traditional face-to-face campaign that was broadcast live through social media, especially Facebook.

The BN campaign never got to effectively utilise social media fully as it needed a collaborative approach to engage with the voters. Instead, BN's strategy for social media was just like its strategy for mass media, that is, 'carpet bombing' messages to the voters. The BN's main message was based around the singlepersona brand of its chairman, even though its approval rating, at a low level of $38 \%$, did not help to erase negative sentiments voters had about the prime minister himself and negative accusations levelled against him. BN's campaign was built on the past glories of how $\mathrm{BN}$ had contributed much to the development of the country. The $\mathrm{PH}$ campaign in many instances sold the Mahathir brand, but the brand offered credibility, with Mahathir advocating reforms to save Malaysia and bring back its glory days. PH built a message of hope, unity, and nationhood. Mahathir's brand gave comfort to rural Malay voters that they could not be wrong to elect Mahathir as the next prime minister because most of them had a good living standard during Mahathir's first stint as prime minister. $\mathrm{PH}$ had announced before the election that Dr. Mahathir would be their prime minister designate should they capture the federal government. Mahathir's brand is very strong among the masses. Once, when Mahathir was openly attacked by the crown prince of one of the states, netizens came to Mahathir 
rescue with more than 10,000 netizens supporting Mahathir within 24 hours (Converse, April 8, 2018).

In collaboration with the main parties, there were many other entities channelling political messages to support their respective parties. In the case of $\mathrm{BN}$, the main supporter is Malaysia Today, a political blog written by Raja Petra, a Malaysian fugitive now living in England. On the other hand, PH has the support of INVOKE, headed by Rafizi Ramli, one of the vice presidents of the $\mathrm{PH}$ coalition Parti Keadilan Rakyat (PKR). INVOKE helps to disseminate messages to targeted voters, campaign in marginalized constituencies, and counter prime-time news from mainstream media with its own 8pm news bulletin, INVOKE News, on live streaming.

There were also grassroots initiatives, especially by voters. When the election was announced to be held on a Wednesday, which is a workday, many thought it was a way to discourage voters from turning out, which might advantage $\mathrm{BN}$; however, it gave birth to social movements such as @CarPoolGE14 and \#PulangMengundi to encourage voters to share transportation to go back to their voting constituencies and vote (Najwa and Amalina, 2018).

Unlike with the mass media, social media users are both the producers and the consumers of information. For social media to be effective, it should not stop at being the courier of information. Social media users need to develop information organically and share it with their networks. Organic information will be better shared among those with the same values. Organic content generated by the voters contributed minimally to positive sentiment for BN. But there was a high volume of negative organic content associated with $\mathrm{BN}$ that was produced by $\mathrm{PH}$ and by voters.

\section{CONCLUSION}

From Obama's and Trump's campaign experiences to Brexit (British Exit) and our local elections, we are witnessing the changing media landscape in election campaigns. While social media's role has become more prominent, we can safely say that its impact differs from place to place. The power of social media is not the same. Its effectiveness rests in how much of the content is relevant and fulfils the needs of the intended users and not in terms of the size of the social media operation being deployed during the campaign period.

\section{REFERENCES}

Digital Marketing Institute. How social media can enhance political campaigns. Retrieved on 15 February 2018. Available at https://digitalmarketinginstitute.com.

Heather, B., Guskin, E., \& Mitchell, A. (2012). Role of social media in the Arab uprisings. Pew Research Center. Retrieved on 27 November 2018 .

Miller, C. (2008). How Obama's Internet campaign changed politics. Bits. Retrieved on 7 November 2018.

Monica Kaminska, John D. Gallacher, Bence Kollanyi, Taha Yasseri, and Philip N. Howard. "Social Media and News Sources during the 2017 UK General Election" Data Memo 2017.6. Oxford, UK:

The Straits Times, 2015. Approval sinks for Malaysian PM Najib's government. Retrieved on 18 October 2018. 
